OPEN ACCESS

Citation: Jinxin Cheng, Dingyu Hu, Yaran Liu, Zetian Zhang, Majid Khayatnezhad (2021) Molecular identification and genetic relationships among Alcea (Malvaceae) species by ISSR Markers: A high value medicinal plant. Caryologia 74(3): 65-75. doi: 10.36253/caryologia-1330

Received: June 07, 2021

Accepted: July 16, 2021

Published: December 21, 2021

Copyright: ( 2021 Jinxin Cheng, Dingyu $\mathrm{Hu}$, Yaran Liu, Zetian Zhang, Majid Khayatnezhad. This is an open access, peer-reviewed article published by Firenze University Press (http://www. fupress.com/caryologia) and distributed under the terms of the Creative Commons Attribution License, which permits unrestricted use, distribution, and reproduction in any medium, provided the original author and source are credited.

Data Availability Statement: All relevant data are within the paper and its Supporting Information files.

Competing Interests: The Author(s) declare(s) no conflict of interest.

\section{Molecular identification and genetic relationships among Alcea (Malvaceae) species by ISSR Markers: A high value medicinal plant}

\author{
Jinxin Cheng ${ }^{1, *}$, Dingyu Hu ${ }^{1}$, YARAn LiU ${ }^{2}$, Zetian Zhang ${ }^{1}$, Majid Khayat- \\ NEZHAD $^{3}$ \\ ${ }^{1}$ China People's Police University, Langfang, Hebei,065000, China \\ ${ }^{2}$ Beijing Forestry University, Beijing 100083, China \\ ${ }^{3}$ Department of Environmental Sciences and Engineering, Ardabil Branch, Islamic Azad \\ University, Ardabil, Iran \\ ${ }^{*}$ Corresponding author. E-mail: jinxin_cheng@163.com
}

\begin{abstract}
Alcea L. is one of the largest genera of Malvaceae family with nearly 70 species worldwide mainly distributed in SW Asia. According to the latest revision of the family, it is represented by 34 species in the Flora of Iran, among them, 15 species are endemic. It is tough to accurate germplasm/ plant recognition by using morphological characteristics because of its propagation, growing and using. We conducted a molecular data analysis on these plant species due to their importance. We examined 156 plants from 14 species in 16 regions that were selected randomly for this investigation. It has been 119 polymorphic bands (94.33\%) were resulted from 128 bands of 10 primers in amplification of genomic DNA. ISSR primers have a great capacity to detect polymorphic loci among Alcea species, as evidenced by the high average PIC and MI values found. The genetic similarity of 14 species was calculated and ranged between 0.635 to 0.990 . Inter-Simple sequence repeats (ISSR) markers research revealed that Alcea tarica Pakravan \& Ghahreman and Alcea kopetdaghensis lljin had the least similarity, while Alcea semnanica Pakravan and Alcea mazandaranica Pakravan \& Ghahreman had the most. The current study attempts to answer three questions: 1) can ISSR markers identify Alcea species? 2) what is the genetic structure of these taxa in Iran? and 3) what is the inter-relationship between these taxa? The current study discovered that ISSR markers can be used to identify species.
\end{abstract}

Keywords: population structure, gene flow, network, genetic admixture.

\title{
INTRODUCTION
}

It is vital to determine the precise boundaries of a species in order to gain a better understanding of any scientific investigations. As a result, in the context of biology, species delimitation is a topic that receives a lot of attention (Collard and Mackill 2009; Wu et al. 2013). However, establishing the criterion that could be used to resolve species borders is a contentious issue (Esfandani-Bozchaloyi et al. 2018a, 2018b, 2018c, 2018d). (Pandey et al. 2008). 
Furthermore, the analysis of wild population genetic structure and the study of intra-specific levels of genetic diversity are critical for the creation of successful conservation measures. The Malvaceae family includes the perennial herb Alcea L., which has its primary centers of diversity in the Western Mediterranean Basin and the Middle East (Zohary 1963a, b, Hutchinson 1973, Riedl 1976, Heywood et al. 1978). In Europe, there are only a few species of Alcea (Escobar et al. 2009). The Flora of Iran has 34 species, 15 of which are endemic, according to the most recent revision of the family (Pakravan 2008) Alcea species are usually tall-growing hemicryptophytes that grow annually, biennially, or perennially. The stem is erect, rarely branching at the base, and occasionally acaulescent. The leaves might be simple, lobed, palmatipartite, or palmatisect in shape. The sepals are five in number and are connate at the base. Petals are pentamerous and come in a variety of colors. Mericarps come in a variety of shapes and sizes, each with a sterile upper chamber and a single seeded bottom chamber. (Ghahreman et al. 2001, Pakravan \& Ghahreman 2006, Pakravan 2006, 2008).

The mucilage that containing the plants of the Malvaceae family are sources of carbohydrates, which are used in medicine (Azizov et al. 2007). The species of this family, especially Alcea rosea has been used as diuretic, demulcents, emollient, aperients, and in the treatment of burning sensation, skin disease, and constipation (Shaheen et al. 2010).

Delimitation of Alcea and Althaea ganera has been a challenging task in taxonomic history of Malvaceae. Alcea has been traditionally included in Althaea based on epicalyx characteristics (Bentham \& Hooker 1862, Baker 1890, Candolle 1837, Edlin 1935, Willdenow 1800). However, characteristics of staminal column and fruit features led to consider Alcea and Althaea as two separate taxa (Alefeled 1862; Boissier 1867; Iljin 1949).

Molecular-phylogenetic data also support the monophyly and distinctness (as suggested by morphological data) of Alcea but they are of limited use in determining relationships between species and species delimitations (Escobar Garsia et al. 2012). The taxonomic complexity of Alcea is remarkable (Zohary 1963a,b, Riedl 1976, Townsend 1980). Alcea has so far proposed two infrageneric classifications, each of which is divided into a few informal groups. Despite the fact that it has a significant number of species, no formal subgeneric categorization has been established. Due to uniformity and pronounced plasticity in morphological characters of this genus (especially in flower and fruit characters), some traits such as leaf sequence, mericarp shape, relative length of calyx versus epicalyx, and indumentum morphology are more applicable in taxonomy of Alcea (Escobar Garcia et al. 2012). For researching genetic diversity, molecular markers are a useful tool. Random Amplified Polymorphic DNA (RAPD) and Inter Simple Sequence Mutation (ISSM) are two sophisticated genetic markers. For diversification assessments, ISSR markers have been routinely used (Pharmawati et al. 2004). The RAPD approach is rapid, simple, and does not require any prior sequence awareness. Then uses a single primer of any nucleotide sequence, the approach detects nucleotide sequence polymorphism (Moreno et al. 1998). A single 16-18 bp. long primer consists of a repeating sequence attached at the 3' or 5' end of 2-4 arbitrary nucleotides is used to amplify DNA for ISSR markers. The method is faster, easier, and less affordable than RAPD, and it is more repeatable (Esfandani-Bozchaloyi et al. 2017a, 2017b, 2017c, 2017d; Collard and Mackill 2009; Wu et al. 2013). The current study used new gene-targeted molecular markers, namely ISSR markers, to assess the genetic diversity and connections among different Alcea species. We conducted a genetic research of 156 collected specimens of 14 Alcea species because this is the first study on the usage of ISSR markers in the Alcea genus.

We try to answer the following questions: 1) Is there infra and interspecific genetic diversity among studied species? 2) Is genetic distance among these species correlated with their geographical distance? 3) What is the genetic structure of populations and taxa? 4) Is there any gene exchange between Alcea species in Iran?

\section{MATERIALS AND METHODS}

\section{Plant materials}

A total of 156 individuals were sampled representing 16 geographical populations belonging to 14 Alcea species in East Azerbaijan, Lorestan, Kermanshah, Mazandaran, Esfahan, Tehran, Khorasan, Semnan, Fars, Golestan Provinces of Iran during July-Agust 2016-2019 (Table 1). We utilized 156 botanical accessions (three to twelve samples of each group) from 16 different populations with various eco-geographic attributes for ISSR analysis which were extracted and stored in -20 until further use. More information about geographical distribution of accessions are in Table 1 and Fig. 1.

During several field excursions to the all part of Iran as well as survey to the several herbaria (Herbarium of Iranian Research Institute of Plant Protection (IRAN), Herbarium of Tehran University (TUH), Herbarium of Shahid Beheshti University (SBUH), and some Herbaria of Natural Resources Research Centers in most provinces of Iran such as: East and West Azerbaijan], some new 
Table 1. Voucher details of Alcea species in this study from Iran.

\begin{tabular}{|c|c|c|c|c|c|}
\hline No & Sp. & Locality & Latitude & Longitude & Altitude (m) \\
\hline Sp1 & Alcea aucheri (Boiss.) Alef. & $\begin{array}{l}\text { Esfahan:Ghameshlou, Sanjab } \\
\text { Kermanshah, Islamabad }\end{array}$ & $38^{\circ} 52^{\prime} 37^{\prime \prime}$ & $47^{\circ} 23^{\prime} 92^{\prime \prime}$ & 1144 \\
\hline Sp2 & Alcea angulata Freyn \& Sint. & Tehran, Damavand & $32^{\circ} 50^{\prime} 03^{\prime \prime}$ & $51^{\circ} 24^{\prime} 28^{\prime \prime}$ & 1990 \\
\hline Sp3 & Alcea rhyticarpa (Trautv.) Iljin & Khorasan, Mashhad & $29^{\circ} 20^{\prime} 07^{\prime \prime}$ & $51^{\circ} 52^{\prime} 08^{\prime \prime}$ & 1610 \\
\hline Sp4 & Alcea sulphurea (Boiss.\& Hohen.) Alef. & Tehran, Tochal & $38^{\circ} 52^{\prime} 37^{\prime \prime}$ & $47^{\circ} 23^{\prime} 92^{\prime \prime}$ & 1144 \\
\hline Sp5 & Alcea striata (DC.) Alef. & $\begin{array}{l}\text { Kermanshah, Islamabad } \\
\text { Esfahan, Semirom }\end{array}$ & $33^{\circ} 57^{\prime} 12^{\prime \prime}$ & $47^{\circ} 57^{\prime} 32 ”$ & 2500 \\
\hline Sp6 & Alcea loftusii (Baker) Zohary & Lorestan, Oshtorankuh, above Tihun village & $34^{\circ} 52^{\prime} 37^{\prime \prime}$ & $48^{\circ} 23^{\prime} 92^{\prime \prime}$ & 2200 \\
\hline Sp7 & $\begin{array}{c}\text { Alcea gorganica (Rech. f., Aellen \& Esfand.) } \\
\text { Zohary }\end{array}$ & Golestan, Gorgan & $38^{\circ} 52^{\prime} 37^{\prime \prime}$ & $47^{\circ} 23^{\prime} 92^{\prime \prime}$ & 1144 \\
\hline Sp8 & Alcea popovii Iljin & Tehran, Chalous & $35^{\circ} 50^{\prime} 03^{\prime \prime}$ & $51^{\circ} 24^{\prime} 28^{\prime \prime}$ & 1700 \\
\hline Sp9 & Alcea mazandaranica Pakravan \& Ghahreman & Mazandaran Province, Kelardasht, Rodbarak & $36^{\circ} 14^{\prime} 14^{\prime \prime}$ & $51^{\circ} 18^{\prime} 07^{\prime \prime}$ & 1807 \\
\hline Sp10 & Alcea tarica Pakravan \& Ghahreman & Tehran, Damavand & $32^{\circ} 36^{\prime} 93^{\prime \prime}$ & $51^{\circ} 27^{\prime} 90^{\prime \prime}$ & 2500 \\
\hline Sp11 & Alcea ghahremanii Pakravan \& Assadi & East Azerbaijan, Arasbaran & $37^{\circ} 07^{\prime} 02^{\prime \prime}$ & $49^{\circ} 44^{\prime} 32^{\prime \prime}$ & 48 \\
\hline Sp12 & Alcea kopetdaghensis lljin & Khorasan, Koppeh Dagh & $28^{\circ} 57^{\prime} 22^{\prime \prime}$ & $51^{\circ} 28^{\prime} 31^{\prime \prime}$ & 430 \\
\hline Sp13 & $\begin{array}{c}\text { Alcea iranshahrii Pakravan, Ghahreman \& } \\
\text { Assadi }\end{array}$ & Fars, Estahban & $30^{\circ} 07^{\prime} 24 ”$ & $53^{\circ} 59^{\prime} 06^{\prime \prime}$ & 2178 \\
\hline Sp14 & Alcea semnanica Pakravan & Semnan, Damghan & $28^{\circ} 57^{\prime} 22^{\prime \prime}$ & $51^{\circ} 28^{\prime} 31^{\prime \prime}$ & 288 \\
\hline
\end{tabular}

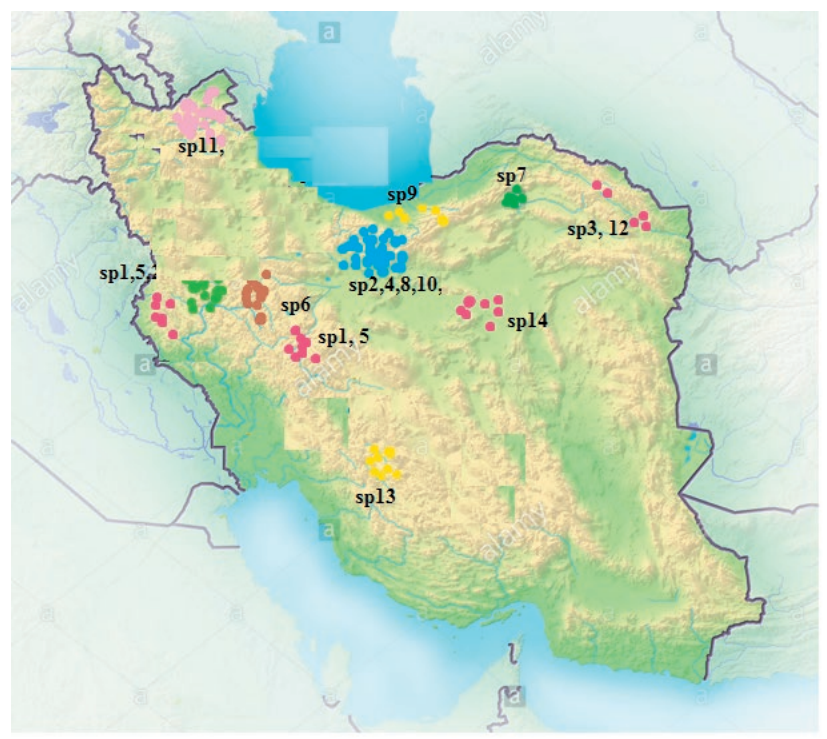

Figure 1. Map of Iran shows the collection sites and provinces where 14 Alcea species were obtained for this study; sp $1=A$. aucheri; $\mathrm{sp} 2=A$. angulata; $\mathrm{sp} 3=A$. rhyticarpa; $\mathrm{sp} 4=$ A. sulphurea; sp5= A. striata; sp 6=A. loftusii ; sp7= A. gorganica; $\mathrm{sp} 8=$ A. popovii; sp9= A. mazandaranica; sp10: A. tarica; sp11: A. ghahremanii; $\mathrm{sp} 12=A$. kopetdaghensis; $\mathrm{sp} 13=A$. iranshahrii; $\mathrm{sp} 14=$ A. semnanica .

information were obtained. The specimens were identified using the identification keys and descriptions of the Alcea species in the relevant floras [Taxonomical Studies in Alcea of South-western Asia (Zohary 1963a, b), Flora
Orientalis (Boissier 1967), Flora Palestina (Zohary 1972), Flora Iranica (Riedl 1976), Flora of Iraq (Townsend et al. 1980), and The Taxonomic Revision of Alcea and Althaea in Turkey (Uzunhisarcikli \& Vural 2012).

\section{DNA extraction and ISSR Assay}

In every one of the tested populations, fresh leaves were also used in random from one to twelve plants. Silica gel powder was used to dry them. To extract genomic DNA, the CTAB activated charcoal procedure was applied (Esfandani-Bozchaloyi et al. 2019). A 0.8 percent agarose gel was used to test the purity of the isolated DNA. 22 primers from the UBC (University of British Columbia) series were evaluated for DNA amplification for the ISSR study. Based on band reproducibility, ten primers were chosen for ISSR study of genetic diversity (Table 2).

PCR reactions were carried in a $25 \mu \mathrm{l}$ volume containing $10 \mathrm{mM}$ Tris- $\mathrm{HCl}$ buffer at $\mathrm{pH} 8 ; 50 \mathrm{mM} \mathrm{KCl} ; 1.5$ $\mathrm{mM} \mathrm{MgCl} 2 ; 0.2 \mathrm{mM}$ of each dNTP (Bioron, Germany); $0.2 \mu \mathrm{M}$ of a single primer; $20 \mathrm{ng}$ genomic DNA and $3 \mathrm{U}$ of Taq DNA polymerase (Bioron, Germany). The following program was used to perform the amplifications and reactions in a Techne thermocycler (Germany): $94^{\circ} \mathrm{C}$ for 5 minutes, then 40 cycles of 1 minute at $94^{\circ} \mathrm{C}, 1$ minute at $52-57^{\circ} \mathrm{C}$, and 2 minutes at $72^{\circ} \mathrm{C}$.

A final extension step of $7-10$ minutes at $72^{\circ} \mathrm{C}$ finished the reaction. Running the amplification results 
Table 2. ISSR primers used for this study and the extent of polymorphism.

\begin{tabular}{lcccccccc}
\hline Primer name & Primer sequence (5'-3') & TNB & NPB & PPB & PIC & PI & EMR & MI \\
\hline ISSR-1 & DBDACACACACACACACA & 15 & 13 & $93.84 \%$ & 0.66 & 4.66 & 11.33 & 4.67 \\
ISSR-2 & GGATGGATGGATGGAT & 12 & 11 & $94.91 \%$ & 0.48 & 5.21 & 12.50 & 5.65 \\
ISSR-3 & GACAGACAGACAGACA & 16 & 14 & $95.74 \%$ & 0.67 & 5.66 & 9.57 & 5.37 \\
ISSR-4 & AGAGAGAGAGAGAGAGYT & 13 & 12 & $92.31 \%$ & 0.54 & 8.21 & 10.23 & 4.55 \\
ISSR-5 & ACACACACACACACACC & 17 & 17 & $100.00 \%$ & 0.47 & 7.32 & 11.55 & 4.18 \\
ISSR-6 & GAGAGAGAGAGAGAGARC & 11 & 10 & $96.89 \%$ & 0.43 & 6.56 & 9.34 & 7.17 \\
ISSR-7 & CTCTCTCTCTCTCTCTG & 13 & 12 & $95.81 \%$ & 0.34 & 4.21 & 6.78 & 5.59 \\
ISSR-8 & CACACACACACACACAG & 12 & 12 & $100.00 \%$ & 0.47 & 3.37 & 9.55 & 3.45 \\
ISSR-9 & GTGTGTGTGTGTGTGTYG & 11 & 9 & $93.89 \%$ & 0.53 & 6.56 & 8.34 & 6.11 \\
ISSR-10 & CACACACACACACACARG & 11 & 11 & $100.00 \%$ & 0.59 & 4.22 & 10.11 & 4.33 \\
\hline Mean & & 12.8 & 11.9 & $94.33 \%$ & 0.55 & 5.32 & 10.66 \\
Total & & 128 & 119 & & & 5.7 \\
\hline
\end{tabular}

Note: TNB - the number of total bands, NPB: the number of polymorphic bands, PPB (\%): the percentage of polymorphic bands, PI: polymorphism index, EMR, effective multiplex ratio; MI, marker index; PIC, polymorphism information content for each of CAAT box- derived polymorphism (CBDP) primers.

over a 1 percent agarose gel and staining with ethidium bromide revealed the amplification products. A 100-bp molecular size ladder was used to assess the fragment size (Fermentas, Germany).

\section{Data analyses - Molecular analyses}

The collected ISSR bands were coded as binary characters (presence $=1$, absence $=0$ ) and utilized to analyze genetic diversity. The UPGMA (Unweighted paired group using average) ordination methods were utilized to sort the plant specimens into groups (Podani 2000). To quantify the capability of each primer to distinguish polymorphic loci amongst these genotypes, two measures, polymorphism information content (PIC) and marker index (MI), were utilized to assess its discriminatory ability (Powell et al. 1996). MI is calculated for each primer as $\mathrm{MI}=\mathrm{PIC} \times \mathrm{EMR}$, where EMR is the product of the number of polymorphic loci per primer $(n)$ and the fraction of polymorphic fragments $(\beta)$ (Heikrujam et al. 2015). For each primer, the effective multiplex ratio (EMR) and the number of polymorphic bands (NPB) were computed. Parameter like Nei's gene diversity $(\mathrm{H})$, Shannon information index (I), number of effective alleles, and percentage of polymorphism ( $\mathrm{P} \%$ =number of polymorphic loci/number of total loci) were determined (Weising et al, 2005, Freeland et al. 2011). Shannon's index was calculated by the formula: $\mathrm{H}^{\prime}=$ $-\Sigma$ piln pi. Rp is defined per primer as: $\mathrm{Rp}=\sum \mathrm{Ib}$, were "Ib" is the band informativeness, that takes the values of 1-(2x [0.5-p]), being " $p$ " the proportion of each genotype containing the band. GenAlEx 6.4 software is used to analyze the percentage of polymorphic loci, the mean loci by accession and population, UHe, H', and PCA (Peakall \& Smouse 2006). Neighbor Joining (NJ) clustering and Neighbor-Net networking were based on Nei's genetic distance between populations (Freeland et al. 2011, Huson \& Bryant 2006). The Mantel test was used to see if there was a link between the analyzed populations' geographical and genetic distances (Podani 2000). The comparison of genetic divergence or genetic distances, estimated by pairwise FST and related statistics, with geographical distances by Mantel test is one of the most popular approaches to evaluate spatial processes driving population structure. The Mantel test, as originally formulated in 1967 ,

$Z_{m}=\sum_{i=1}^{n} \sum_{j=1}^{n} g_{i j} \times d_{i j}$

Where $g i j$ and $d i j$ are, respectively, the genetic and geo-graphic distances between populations $i$ and $j$, considering populations. Because $\mathrm{Zmis}$ given by the sum of products distances its value depends on how many populations are studied, as well as the magnitude of their distances. The $\mathrm{Zm}$-value can be compared with a null distribution, and Mantel originally proposed to test it by the standard normal deviate (SND), given by $\mathrm{SND}=\mathrm{Zm} / \operatorname{var}(\mathrm{Zm}) 1 / 2$ (Mantel 1967). These analyses were done by PAST ver. 2.17 (Hammer et al. 2012), DARwin ver. 5 (2012) software. To show genetic differences between the populations, the AMOVA (Analysis of molecular variance) test (with 1000 permutations) was utilized, which was implemented in GenAlex 6.4 


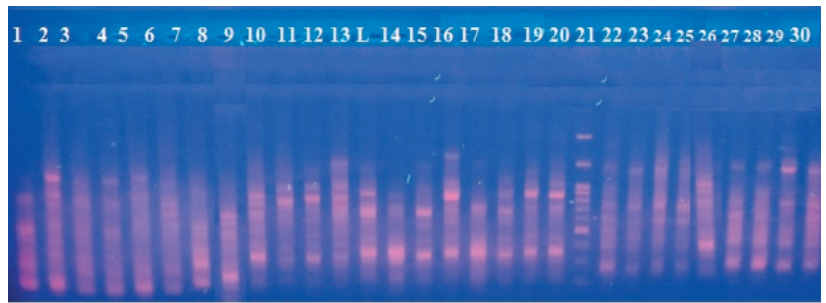

Figure 2. Electrophoresis gel of Alcea species from DNA fragments produced by ISSR-5 and ISSR-3; sp1,14= A. aucheri; sp2,15= A. angulata; $\mathrm{sp} 3,16=A$. rhyticarpa $; \mathrm{sp} 4,17=A$. sulphurea; $\mathrm{sp} 5,18=$ A. striata; sp $6,19=A$. loftusii; sp7,20=A. gorganica; sp8,21=A. popovii; sp9,22= A. mazandaranica; sp10,23: A. tarica; sp11,24: A. ghahremanii; sp12,25=A. kopetdaghensis; sp13,26=A. iranshahrii; sp14,27= A. semnanica.

(Peakall \& Smouse 2006). This approach considers the equal amount of gene flow among all populations. The genetic structure of populations was studied by Bayesian based model STRUCTURE analysis (Pritchard et al. 2000), and maximum likelihood-based method of K-Means clustering of GenoDive ver. 2 (2013). Data were evaluated as dominating markers for STRUCTURE analysis (Falush et al. 2007). Under the correlated allele frequency model, we used the admixture ancestry model. After a 105 burn-in period, a Markov chain Monte Carlo simulation was ran 20 times for each value of $\mathrm{K}$. Using the delta $\mathrm{K}$ value, the Evanno test was run on the STRUCTURE result to determine the right number of K. (Evanno et al. 2005)

\section{RESULTS}

\section{Species identification and genetic diversity}

To examine genetic links among Alcea species, ten ISSR primers were tested; all of the primers yielded replicable polymorphic bands in all 14 Alcea species. Figure 2 depicts the ISSR amplification induced by the ISSR- 5 primer. Across 14 Alcea species, a total of 119 amplified polymorphic bands were produced. The amplified fragments were between 100 and 3000 bp in length. With an average of 11.9 polymorphic bands per primer, ISSR-5 had the most and lowest number of polymorphic bands, with 17 and 9 respectively. The average PIC of the 10 ISSR primers was 0.55 , ranging from 0.34 (ISSR-7) to 0.67 (ISSR-3). The MI of the primers ranged from 3.45 (ISSR-8) to 7.17 (ISSR-6) on average, with an average of 5.7. ISSR primers had an EMR ranging from 6.78 (ISSR7) to 12.50 (ISSR-2), with an average of 10.66 per primer (Table 2). The primers with the highest EMR values were thought to be more useful in separating the genotypes. The genetic parameters for all 14 Alcea species amplified with ISSR primers were calculated (Table 3 ). Unbiased expected heterozygosity $(H)$ ranged from 0.15 (Alcea popovii) to 0.39 (Alcea aucheri), with a mean of 0.28 . Shannon's information index (I) showed a similar pattern, with the greatest value of 0.39 in Alcea aucheri and the lowest value of 0.10 in (Alcea popovii), with a mean of 0.27 . The number of alleles $(\mathrm{Na})$ observed in Alcea rhyticarpa ranged from 0.201 to 0.645 in Alcea kopetdaghensis. The effective number of alleles $(\mathrm{Ne})$ in

Table 3. Genetic diversity parameters in the studied Alcea species.

\begin{tabular}{|c|c|c|c|c|c|c|c|c|}
\hline SP & & $\mathrm{N}$ & $\mathrm{Na}$ & $\mathrm{Ne}$ & I & $\mathrm{He}$ & $\mathrm{UHe}$ & $\% \mathrm{P}$ \\
\hline Sp1 & Alcea aucheri & 5.000 & 0.462 & 1.095 & 0.398 & 0.48 & 0.39 & $76.55 \%$ \\
\hline $\mathrm{Sp} 2$ & Alcea angulata & 8.000 & 0.399 & 1.167 & 0.322 & 0.398 & 0.344 & $65.77 \%$ \\
\hline Sp3 & Alcea rhyticarpa & 8.000 & 0.201 & 0.095 & 0.23 & 0.27 & 0.22 & $42.23 \%$ \\
\hline $\mathrm{Sp} 4$ & Alcea sulphurea & 5.000 & 0.341 & 1.058 & 0.24 & 0.27 & 0.20 & $53.75 \%$ \\
\hline Sp5 & Alcea striata & 5.000 & 0.455 & 1.077 & 0.277 & 0.24 & 0.22 & $55.05 \%$ \\
\hline Sp6 & Alcea loftusii & 8.000 & 0.499 & 1.067 & 0.24 & 0.23 & 0.24 & $49.26 \%$ \\
\hline Sp7 & Alcea gorganica & 6.000 & 0.555 & 1.020 & 0.22 & 0.25 & 0.28 & $43.53 \%$ \\
\hline Sp8 & Alcea popovii & 10.000 & 0.431 & 1.088 & 0.20 & 0.22 & 0.25 & $41.53 \%$ \\
\hline Sp9 & Alcea mazandaranica & 3.000 & 0.255 & 1.021 & 0.25 & 0.28 & 0.22 & $47.15 \%$ \\
\hline Sp10 & Alcea tarica & 9.000 & 0.261 & 1.024 & 0.292 & 0.23 & 0.23 & $43.15 \%$ \\
\hline Sp11 & Alcea ghahremanii & 12.000 & 0.287 & 1.253 & 0.266 & 0.254 & 0.28 & $51.99 \%$ \\
\hline Sp12 & Alcea kopetdaghensis & 3.000 & 0.645 & 1.062 & 0.24 & 0.224 & 0.213 & $44.73 \%$ \\
\hline Sp13 & Alcea iranshahrii & 8.000 & 0.499 & 1.067 & 0.24 & 0.281 & 0.24 & $49.26 \%$ \\
\hline Sp14 & Alcea semnanica & 12.000 & 0.287 & 1.233 & 0.271 & 0.284 & 0.292 & $51.91 \%$ \\
\hline
\end{tabular}

Abbreviations: $\mathrm{N}$ = number of samples, $\mathrm{Na}=$ number of different alleles; $\mathrm{Ne}=$ number of effective alleles, $\mathrm{I}=$ Shannon's information index, $\mathrm{He}=$ gene diversity, $\mathrm{UHe}=$ unbiased gene diversity, $\mathrm{P} \%=$ percentage of polymorphism, populations. 
Table 4. Analysis of molecular variance (AMOVA) of the studied species.

\begin{tabular}{lcccccc}
\hline Source & df & SS & MS & Est. Var. & $\%$ & $\Phi P T$ \\
\hline Among Pops & 29 & 1601.364 & 45.799 & 15.194 & $67 \%$ & \\
Within Pops & 122 & 454.443 & 1.905 & 2.884 & $33 \%$ & $67 \%$ \\
Total & 151 & 2033.807 & & 17.020 & $100 \%$ & \\
\hline
\end{tabular}

df: degree of freedom; SS: sum of squared observations; MS: mean of squared observations; EV: estimated variance; $\boldsymbol{\Phi P T}$ : proportion of the total genetic variance among individuals within an accession, $(\mathrm{P}<0.001)$.

these species ranged from 0.095 (Alcea rhyticarpa) to 1.253 (Alcea ghahremanii). The AMOVA test revealed a substantial genetic difference $(\mathrm{P}=0.001)$ between the species investigated. It was discovered that 67 percent of overall variance was found across species, whereas 33 percent was found within species (Table 4). Significant Nei's GST $(0.245, \mathrm{P}=0.001)$ and $\mathrm{D}$ est $(0.765, \mathrm{P}=0.001)$ values further indicated the genetic difference of these species. In comparison to within-species genetic diversity, these findings demonstrated a larger distribution of genetic variety within Alcea species.

\section{Species identification and inter-relationship}

Because the results of other clustering and ordination approaches were similar, PCA plot and UPGMA clustering are provided here (Figure 3-4). Plant samples from different species were put together and formed various groups in general. This study demonstrates that the examined species were divided into several groups based on molecular characteristics. We didn't find any intermediate forms in the specimens we looked at. The dendrogram based on ISSR data was constructed by UPGMA analysis, grouping all of the Alcea species into two major clusters (Fig. 4). The first major cluster divided into two minor clusters of which the first minor cluster again divided into two sub-minor clusters. The first subminor cluster consisted of A. aucheri; A. rhyticarpa and A. striata. The second sub-minor cluster was represented by $A$. angulata; $A$. sulphurea. The second major cluster divided in to two minor clusters of which the first minor cluster consisted of A. loftusii, A. gorganica and A. popo$v i$. The second sub-minor cluster was represented by $A$. kopetdaghensis, A. mazandaranica, A. tarica, A. ghahremanii, A. iranshahrii; and A. semnanica. This is consistent with the AMOVA and genetic diversity metrics previously reported. Genetically, the species are distinct from one another. ISSR molecular markers can be employed to taxonomist Alcea species, according to these findings.

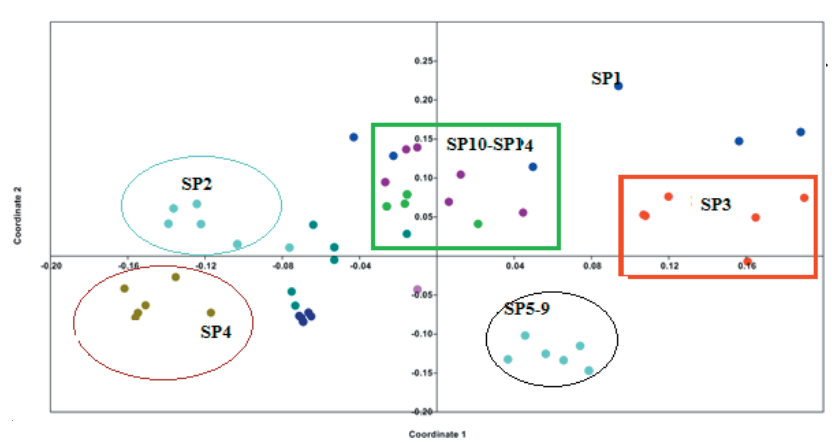

Figure 3. PCA plots of based on ISSR data revealing species delimitation in Alcea species; $\mathrm{sp} 1=A$. aucheri; $\mathrm{sp} 2=A$. angulata $; \mathrm{sp} 3=A$. rhyticarpa; $\mathrm{sp} 4=A$. sulphurea; $\mathrm{sp} 5=A$. striata; sp $6=A$. loftusii ; $\mathrm{sp} 7=$ A. gorganica; $\mathrm{sp} 8=$ A. popovii; $\mathrm{sp} 9=A$. mazandaranica; $\mathrm{sp} 10$ : A. tarica; sp11: A. ghahremanii; sp12= A. kopetdaghensis; $\mathrm{sp13}=A$. iranshahrii; sp14= A. semnanica.

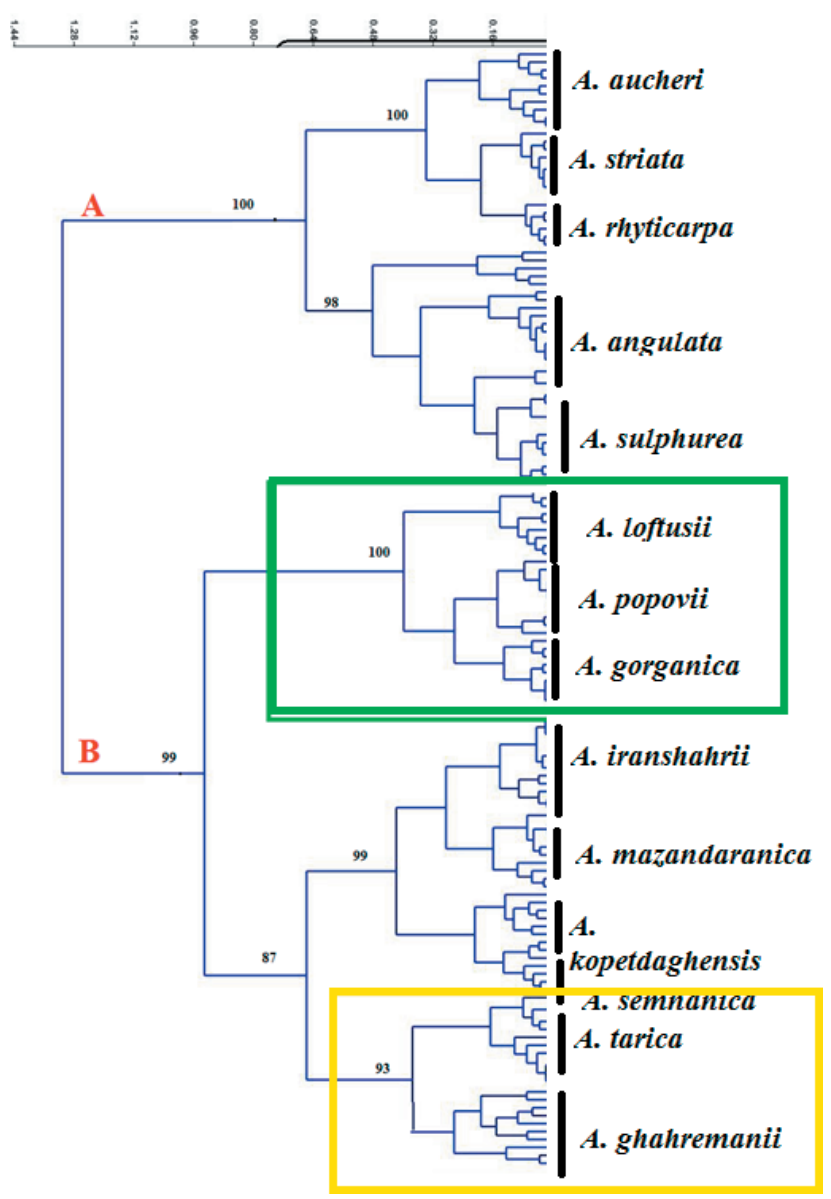

Figure 4. Dendrogram generated using the unweighted pair group method with arithmetic average (UPGMA) analysis showing relationships among different Alcea species using ISSR data. 
Table 5. The matrix of Nei genetic similarity (Gs) estimates using ISSR molecular markers among 14 Alcea species. sp1=A. aucheri; sp2=A. angulata; $\mathrm{sp} 3=$ A. rhyticarpa; $\mathrm{sp} 4=$ A. sulphurea; $\mathrm{sp} 5=$ A. striata; $\mathrm{sp}$ 6=A. loftusii; $\mathrm{sp} 7=$ A. gorganica $; \mathrm{sp} 8=$ A. popovii; $\mathrm{sp} 9=$ A. mazandaranica; sp10: A. tarica; sp11: A. ghahremanii; sp12= A. kopetdaghensis; sp13= A. iranshahrii; sp14= A. semnanica

\begin{tabular}{|c|c|c|c|c|c|c|c|c|c|c|c|c|c|c|c|}
\hline sp1 & 1.000 & & & & & & & & & & & & & & sp1 \\
\hline $\mathrm{sp} 2$ & 0.887 & 1.000 & & & & & & & & & & & & & $\mathrm{sp} 2$ \\
\hline $\mathrm{sp} 3$ & 0.891 & 0.744 & 1.000 & & & & & & & & & & & & sp3 \\
\hline sp4 & 0.738 & 0.787 & 0.842 & 1.000 & & & & & & & & & & & $\mathrm{sp} 4$ \\
\hline sp5 & 0.705 & 0.742 & 0.745 & 0.775 & 1.000 & & & & & & & & & & sp5 \\
\hline sp6 & 0.778 & 0.891 & 0.744 & 0.936 & 0.838 & 1.000 & & & & & & & & & sp6 \\
\hline sp7 & 0.599 & 0.702 & 0.808 & 0.875 & 0.836 & 0.862 & 1.000 & & & & & & & & $\mathrm{sp} 7$ \\
\hline sp8 & 0.754 & 0.785 & 0.676 & 0.829 & 0.733 & 0.800 & 0.709 & 1.000 & & & & & & & sp8 \\
\hline sp9 & 0.757 & 0.741 & 0.758 & 0.816 & 0.740 & 0.785 & 0.676 & 0.725 & 1.000 & & & & & & sp9 \\
\hline sp10 & 0.737 & 0.890 & 0.722 & 0.719 & 0.853 & 0.741 & 0.758 & 0.834 & 0.746 & 1.000 & & & & & sp10 \\
\hline sp11 & 0.807 & 0.799 & 0.755 & 0.812 & 0.774 & 0.990 & 0.722 & 0.768 & 0.800 & 0.721 & 1.000 & & & & sp11 \\
\hline sp12 & 0.782 & 0.744 & 0.636 & 0.834 & 0.750 & 0.799 & 0.755 & 0.720 & 0.785 & 0.635 & 0.839 & 1.000 & & & sp12 \\
\hline sp13 & 0.702 & 0.757 & 0.703 & 0.778 & 0.691 & 0.744 & 0.636 & 0.829 & 0.741 & 0.750 & 0.799 & 0.642 & 1.000 & & sp13 \\
\hline sp14 & 0.751 & 0.774 & 0.732 & 0.790 & 0.750 & 0.797 & 0.812 & 0.774 & 0.990 & 0.675 & 0.727 & 0.728 & 0.684 & 1.000 & sp14 \\
\hline
\end{tabular}

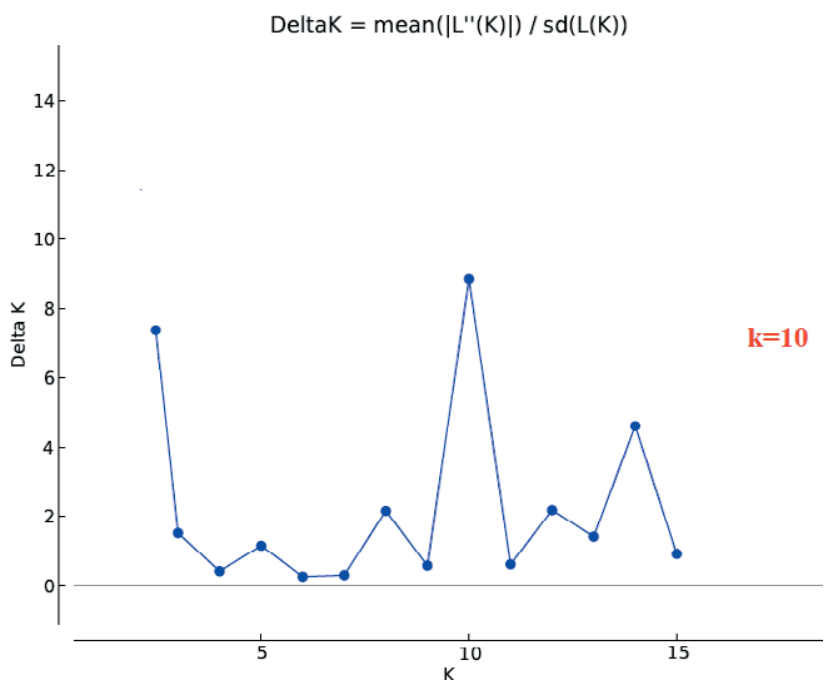

Figure 5. Evanno test produced $\Delta \mathrm{K}=10$ of ISSR data in Alcea species. degree of genetic resemblance (0.99). Between Alcea tarica and Alcea kopetdaghensis, there was the least genetic affinity (0.63). The low Nm value (0.47) implies little gene flow or ancestrally shared alleles between the species investigated, as well as considerable genetic divergence between and within Alcea species.

To determine the ideal number of genetic groups, we used STRUCTURE analysis followed by the Evanno test. In the species analyzed, we employed the admixture model to show interspecific gene flow and/or ancestrally shared alleles.

STRUCTURE analysis followed by Evanno test produced $\Delta \mathrm{K}=10$ (Fig. 5). The STRUCTURE plot (Fig. 6) produced more detailed information about the genetic structure of the species studied as well as shared ancestral alleles and/ or gene flow among Alcea species. This plot revealed that Genetic affinity between Alcea aucheri and $A$. sulphurea (similarly colored, No. 1,4), as well as A. gorganica; A. popovii and A. semnanica; (No. 7,8,14)

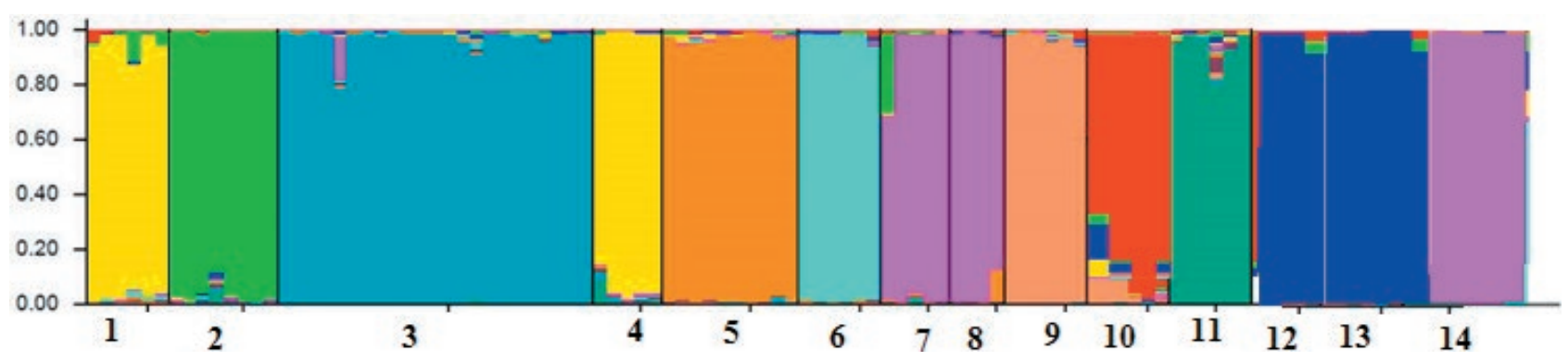

Figure 6. STRUCTURE plot of ISSR data in Alcea species. $\mathrm{sp} 1=A$. aucheri; $\mathrm{sp} 2=$ A. angulata; $\mathrm{sp} 3=$ A. rhyticarpa; $\mathrm{sp} 4=A$. sulphurea; $\mathrm{sp} 5=$ A. striata; sp $6=$ A. loftusii; sp7= A. gorganica; $\mathrm{sp} 8=$ A. popovii; sp9=A. mazandaranica; sp10: A. tarica; sp11: A. ghahremanii; sp12= A. kopetdaghensis; $\mathrm{sp13}=$ A. iranshahrii; sp14= A. semnanica. 


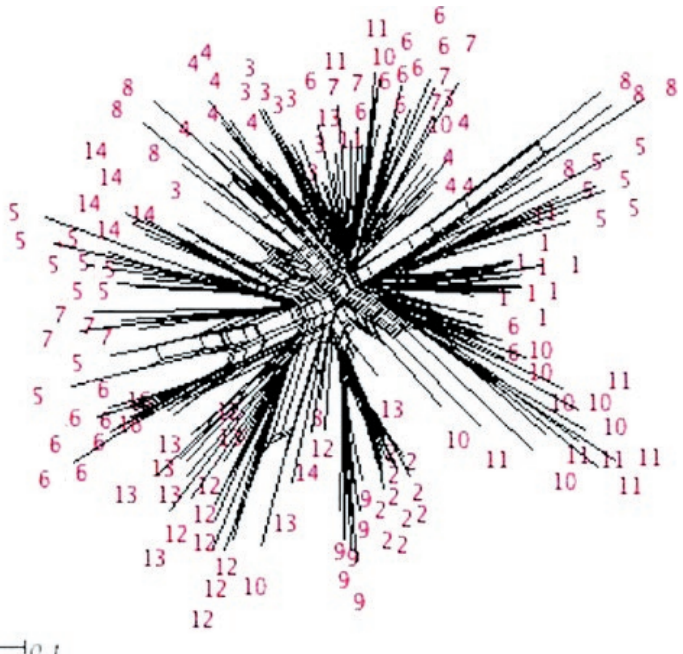

Figure 7. Neighbor-Net of ISSR data in Alcea species. sp1=A. aucheri; $\mathrm{sp} 2=A$. angulata $; \mathrm{sp} 3=A$. rhyticarpa $; \mathrm{sp} 4=A$. sulphurea; sp5 $=$ A. striata; sp $6=A$. loftusii; $\mathrm{sp} 7=A$. gorganica $; \mathrm{sp} 8=A$. popovii; $\mathrm{sp} 9=$ A. mazandaranica; sp10: A. tarica; sp11: A. ghahremanii; sp12= A. kopetdaghensis; sp13=A. iranshahrii; sp14= A. semnanica

due to shared common alleles. This is in agreement with UPGMA dendrogram presented before. The other species are distinct in their allele composition. The NeighborNet diagram (Fig. 7) also revealed almost complete separation of the studied species within the network, supporting the AMOVA results. Populations 1,2 and 12,13 are distinct and stand separately from the other populations at a great distance. Populations 6 and 7 and populations 10 and 11 show a closer genetic affinity and are placed close to each other.

\section{DISCUSSION}

In the biology of long-term evolution of a group of animals or species, genetic diversity plays a crucial role. The foundation for a taxon's presence, development, and evolution. To recognize the taxonomy, origin, and evolution of a taxon, it is necessary to investigate its genetic diversity. In addition, such study could provide a theoretical foundation for the conservation, expansion, exploitation, and breeding of germplasm resources (Lubbers et al. 1991). The current study provided fascinating information about genetic variability, genetic stratification, and morphological difference in Iran's north and west. The degree of genetic variability within a species is significantly connected with its reproduction method; the higher the degree of open pollination/cross breeding, the greater the genetic variability in the taxon under study (Meusel et al. 1965). A primer's PIC and MI features aid in establishing its efficacy in genetic diversity analysis. The ability of a marker technique to resolve genetic variability, according to Sivaprakash et al. (2004), may be more directly connected to the degree of polymorphism. PIC values ranging from zero to 0.25 indicate relatively low genetic variation among genotypes, 0.25 to 0.50 indicate a mid-level of genetic diversity, and $\geq 0.50$ indicate a high level of genetic diversity (Tams et al. 2005). The PIC values of the ISSR primers in this study ranged from 0.34 to 0.66 , with a mean value of 0.55 , indicating that ISSR primers have a good level of competence in detecting genetic diversity among Alcea species. In the Alcea taxon, all ten primer pairs demonstrated good polymorphism. For the species under investigation, a total of 128 alleles were discovered. The total number of polymorphic bands per primer varied from 9 to 17 , and the average allele number in loci was 11.9. Occurrence of high polymorphism could be explained for species in different climatic zones with varying selection pressure during the course of evolution (Mishra et al. 2011).

In most studies, population size is limited to several vegetative accession (Meusel et al. 1965; Uotila 1996). This population could be showed genetic drift, whose effect are observed in the high level of $\mathrm{F}_{\mathrm{IS}}$ and low level of genetic diversity. The isolation of the population and absence the gene flow led to fragmentation of the Alcea populations. Between genetic diversity parameters and population size were showing positive correlations that confirmed various studies (Leimu et al. 2006). There are two reasons for the positive correlation between genetic diversity and population size (Leimu et al. 2006). 1- A positive connection may confirmed the existence of an extinction vortex, in which declining population reduces genetic variety, resulting in inbreeding depression.

Plant fitness separates populations depending on habitat quality changes, which is the second cause. Low levels of genetic variation, according to Booy et al. (2000), can impair plant fitness and limit a population's capabilities to react to environmental changes by selection and adaptation.

Genetic diversity (33\%) was obtained within populations, whereas $67 \%$ of genetic variation obtained between the evaluated populations. The breeding system in plant species is one of the primary elements controlling the distribution of genetic variation (Duminil 2007). Couvet (Booy et al. 2000) shown that one migrant each generation is insufficient to ensure long-term persistence of tiny populations, and that the number of migrants is determined by family background characteristics and population genetics (Vergeer et al. 2003). For the lack of distinctions across isolated groups, there are two explanations. The initial theory proposed that genetic variety 
in and between populations demonstrates gene flow patterns, resulting in group splitting (Dostálek et al. 2010). Geographically close communities are far more successfully associated via gene flow than populations segregated by considerable distance, according to the next objective. Merely a few research have investigated into Alcea's genetic diversity thus far. Kazemi et al. (2011) found a 93 percent polymorphism ratio with strong genetic resemblance (0.31 to 0.75$)$ within $A$. rosea species in Iran using RAPD identifiers analysis. Utilizing RAPD markers, Oztürk et al. (2009) evaluated the genetic profiles of 18 Alcea species and found wide difference (0.13 to 0.69) throughout them. According to Badrkhani et al. (2014), the sequence-related amplified polymorphism (SRAP) identifier was used to evaluate the genetic diversity and genetic similarity links among 14 Alcea species were collected from the northwest of Iran. Seventeen SRAP primer pairings produced 104 segments, with an average of 5.7 polymorphic fragments per primer. The percentage of polymorphism spanned from 50\% (ME2-EM6) to $100 \%$ (ME2-EM6), with an average polymorphism information content value of 0.3 . The genetic similarity between A. sophiae and A. flavovirens was the lowest (0.17), while the highest was identified between $A$. digitata and A. longipedicellata (0.68). Using UPGMA, two primary clusters were discovered, neither of which corresponded to the species' geographical origin. According to their findings, SRAP markers may be suitable for analyzing genetic diversity in Alcea. So far, only morphological data has been used to define Iranian Alcea species. However, due to the very small number of characteristics, the genus has a challenging taxonomy. According to Pakravan's (2008) study on Alcea, only the leaf sequence and carpel structure are valuable traits.

Escobar Garcia et al. (2012) with using three molecular markers (nrDNA ITS and the plastid spacers $p s b A$ $\operatorname{trnH}$ and $\operatorname{trnL}$-trnF), showed that a phylogeny of Alcea and test previous infrageneric taxonomic hypotheses as well as its monophyly with respect to Althaea, a genus with which it has often been merged. They also go into morphological variation and the use of morphological features as phylogenetic association indicators. While molecular findings indisputably corroborate the circumscription of Alcea deduced from morphology, they are of limited usefulness in clarifying interspecific relationships, implying that Alcea's great species diversity is attributable to swift and early radiation. Their research establishes the first Alcea phylogeny and intends to pave the way for future research into the processes that underpin species radiation in the Irano-Turanian region.

In conclusion, the results of this study showed that to evaluate the genetic diversity of the Alcea genus in the
Irano-Turanian region, a main center of species diversity for many medium-sized to large genera that remains greatly understudied. ISSR-derived primers were more successful than those produced from all other molecular markers. In addition, Alcea species were clearly distinguished from one another in the dendrogram and PCA, demonstrating that the ISSR approach is more effective in identifying Alcea species.

\section{ACKNOWLEDGMENT}

Key R\&D projects in HeBei Province(19275416D). Key R\&D projects in China People's Police University (ZDX202101).

\section{REFERENCES}

Azizov U.M., Mirakilova D.B., Umarova N.T., Salikhov S.A., Rakhimov D.A. and Mezhlumyan L.G.2007. Chemical composition of dry extracts from Alcea rosea. Chemistry of Natural Compounds 43:508-511.

Alefeld, F.G.C. 1862. Ueber die Malveen. Oesterreichische Botanische Zeitschrift 12:246-261.

Boissier P.E. 1867. Flora Orientalis, Vol. 1. Basel, Geneva, Leiden.

Baker EG. 1890. Synopsis of genera and species of Malveae. Journal of Botany 28:140-371.

Bentham G. \& Hooker JD. (1862-1883). Genera Plantarum Vol. II. London.

Booy G, Hendriks RJJ, Smulders MJM, Van Groenendael JM, Vosman B. 2000. Genetic diversity and the survival of populations. Plant Biol. 2:379-395.

Candolle APde. 1837. Prodromus sytematis naturalis regni vegetabilis. Paris: Sumptibus Sociorum Treuttel et Wurtz 3:207-296.

Collard BCY. Mackill DJ. 2009. Start codon targeted (SCoT) polymorphism: a simple novel DNA marker technique for generating gene-targeted markers in plants. Plant Mol Biol Rep 27:86-93.

Duminil J, Fineschi S, Hampe A, Jordano P, Salvini D, Vendramin GG. 2007. Can population genetic structure be predicted from life-history traits? Amer Nat. 169:662-672.

Dostálek T, Münzbergová Z, Plačková I. 2010. Genetic diversity and its effect on fitness in an endangered plant species, Dracocephalum austriacum L. Conserv Genet. 11:773-783.

Edlin HL. 1935. A critical revision of certain taxonomic groups of the Malvales part ii, 1.vNew Phytologist 34(2):122-143. 
Escobar García, P., Pakravan M., Schönswetter P., Aguilar J.F. \& Schneeweiss GM. 2012.vPhylogenetic relationships in the species-rich Irano-Turanian genus Alcea (Malvaceae). Taxon 61(2):324-332.

Esfandani-Bozchaloyi S, Sheidai M, Keshavarzi M, Noormohammadi Z 2017a. Genetic Diversity and Morphological Variability In Geranium Purpureum Vill. (Geraniaceae) Of Iran. Genetika 49: 543-557. https:// doi.org/10.2298/GENSR1702543B

Esfandani-Bozchaloyi S, Sheidai M, Keshavarzi M, Noormohammadi Z 2017b. Species Delimitation In Geranium Sect. Batrachioidea: Morphological and Molecular. Act Bot Hung 59(3-4):319-334. doi: 10.1556/034.59.2017.3-4.3

Esfandani-Bozchaloyi S, Sheidai M, Keshavarzi M, Noormohammadi Z 2017c. Genetic and morphological diversity in Geranium dissectum (Sec. Dissecta, Geraniaceae) populations. Biologia 72(10):1121-1130. DOI: 10.1515/biolog-2017-0124

Esfandani-Bozchaloyi S, Sheidai M, Keshavarzi M, Noormohammadi Z 2017d. Analysis of genetic diversity in Geranium robertianum by ISSR markers. Phytologia Balcanica 23(2):157-166.

Esfandani-Bozchaloyi S, Sheidai M, Keshavarzi M, Noormohammadi Z 2018a. Species Relationship and Population Structure Analysis In Geranium Subg. Robertium (Picard) Rouy with The Use of ISSR Molecular Markers. Act Bot Hung, 60(1-2):47-65.

Esfandani-Bozchaloyi S, Sheidai M, Keshavarzi M, Noormohammadi Z 2018b. Species Identification and Population Structure Analysis In Geranium Subg. Geranium (Geraniaceae). Hacquetia, 17(2):235-246 DOI: 10.1515/hacq-2018-0007

Esfandani -Bozchaloyi S, Sheidai M, Keshavarzi M, Noormohammadi Z 2018c. Morphometric and ISSR-analysis of local populations of Geranium molle L. from the southern coast of the Caspian Sea. Cytology and genetics, 52(4):309-321.

Esfandani -Bozchaloyi S, Sheidai M,2018d. Molecular diversity and genetic relationships among Geranium pusillum and $G$. pyrenaicum with inter simple sequence repeat (ISSR) regions, Caryologia 71(4):114. https://doi.org/10.1080/00087114.2018.1503500

Esfandani-Bozchaloyi S, Sheidai M, 2019. Comparison Of Dna Extraction Methods From Geranium (Geraniaceae), Acta Botanica Hungarica 61(3-4):251-266.

Escobar G.P., Schönswetter P., Fuertes A.J., Nieto F.G. and Schneeweiss G.M. 2009. Five molecular markers reveal extensive morphological homoplasy and reticulate evolution in the Malva alliance (Malvaceae). Molecular Phylogenetics and Evolution 50:226-239.

Freeland JR, Kirk H. Peterson SD. 2011. Molecular Ecology (2nded). Wiley-Blackwell, UK, 449 pp.
Ghahreman A., Pakravan M. \& Assadi M. 2001. A new species of Alcea (Malvaceae) from Iran. Nordic Journal of Botany 20(6):701-704.

Gholamin R. \& Khayatnezhad M. 2020a. Assessment of the Correlation between Chlorophyll Content and Drought Resistance in Corn Cultivars (Zea Mays). Helix 10:93-97.

Gholamin R. \& Khayatnezhad M. 2020b. The effect of dry season stretch on Chlorophyll Content and RWC of Wheat Genotypes (Triticum Durum L.). Bioscience Biotechnology Research Communications, 13:1833-1829.

Gholamin R. \& Khayatnezhad M. 2020c. Study of Bread Wheat Genotype Physiological and Biochemical Responses to Drought Stress. Helix 10:87-92.

Huson DH. Bryant D. 2006. Application of Phylogenetic Networks in Evolutionary Studies. Molecular Biology and Evolution 23:254-267.

Hammer O, Harper DA. Ryan PD. 2012. PAST: Paleontological Statistics software package for education and data analysis. Palaeonto Electro 4:9.

Heywood VH, Moore DM, Dunkley J. \& King C. (eds). 1978. Flowering Plants of the World. Oxford University Press, Oxford, 366 pp.

Hutchinson J. 1973. The Families of Flowering Plants (Angiospermae): Dicotyledons. Oxford University Press Oxford.

Heikrujam M, Kumar J. Agrawal V. 2015. Genetic diversity analysis among male and female Jojoba genotypes employing gene targeted molecular markers, start codon targeted (SCoT) polymorphism andCAAT box-derived polymorphism (CBDP) markers. Meta Gene 5:90-97.

Iljin MM. 1949. Malvaceae. Flora of the USSR 15:21-137.

Kazemi M., Aran M. and Zamani S. 2011. Evaluation of genetic diversity of Iranian wild Alcea rosea population using RAPD. World Applied Sciences Journal 13:1234-1239.

Lubbers EL, Gill KS, Cox TS, Gill BS. 1991. Variation of molecular markers among geographically diverse accessions of Triticum tauschii. Genome 34:354-361

Leimu R, Mutikainen P, Koricheva J, Fischer M. 2006. How general are positive relationships between plant population size, fitness and genetic variation? J Ecol. 94:942-952.

Meusel H, Jäger EJ, Weinert E. 1965. Vergleichende Chorologie der zentraleuropäischen Flora. Text u. Karten. Bd. 1. VEB Fischer, Jena.

Mishra MK., Nishani S. and Jayarama. 2011. Molecular identification and genetic relationships among Coffee species (Coffee L.) inferred from ISSR and SRAP marker analyses. Archives of Biological Science, Belgrade 63:667-679. 
Öztürk F., Babaoğlu S., Uzunhisarcikli M.E., Açik L., Vural M. and Gürcan I.S. 2009. Genetic differentiation of Turkish Althaea L. and Alcea L. species. Advances in Molecular Biology 1:47-56.

Pakravan M. 2008. A new species and a new combination in Iranian Alcea (Malvaceae). Annales Botanici Fennici 45:133-136.

Pakravan M. \& Ghahreman A. 2006. Two ne species of Alcea from Iran. Rostaniha 6(2):151-152.

Pakravan M. 2006. Novelties in Alcea (Malvaceae) from Iran. Iranian Journal of Botany 12(2):183-186.

Pandey A, Tomer AK, Bhandari D, Pareek S. 2008. Towards collection of wild relatives of crop plants in India. Genet Resour Crop Evol 55(2):187-202

Peakall R. Smouse PE. 2006. GENALEX 6: genetic analysis in Excel. Population genetic software for teaching and research. Molecular Ecology Notes 6:288-295.

Podani J. 2000. Introduction to the Exploration of Multivariate Data English translation. Backhuyes publisher, Leide, $407 \mathrm{pp}$.

Powell W, Morgante M, Doyle JJ, McNicol JW, Tingey SV. Rafalski A J. 1996. Gene pool variation in genus Glycine subgenus Soja revealed by polymorphic nuclear and chloroplast microsatellites. Genetics 144, 79-803.

Riedl I. 1976. Malvaceae. In: Rechinger K.H. Ed. Flora Iranica 120, pp 1-86, Akademische Druck und Verlagsanstalt, Graz.

Shaheen N., Khan M.A., Yasmin G., Hayat M.Q., Munsif S. and Ahmad K. 2010. Foliar epidermal anatomy and pollen morphology of the genera Alcea and Althaea (Malvaceae) from Pakistan. International Journal of Agriculture and Biology 12:329-334.

Sivaprakash KR, Prasanth S R, Mohanty BP. Parida A. 2004. Genetic diversity of black gram landraces as evaluated by AFLP markers. Curr. Sci. 86:1411-1415.

Townsend CC., Guest E. \& Al-Rawi A. 1966-1985. Flora of Iraq. Ministry of Agriculture of the Republic of Iraq. Baghdad.

Tams SH, Melchinger AE. Bauer E. 2005. Genetic similarity among European winter triticale elite germplasms assessed with AFLP and comparisons with SSR and pedigree data. Plant Breed. 124:154-160.

Uzunhisarcikli ME. \& Vural M. 2012. The taxonomic revision of Alcea and Althaea (Malvaceae) in Turkey. Turkish Journal of Botany 36(6):603-636.

Wu JM, Li YR, Yang LT, Fang FX, Song HZ, Tang HQ, Wang M. Weng ML. 2013. cDNA-SCoT: a novel rapid method for analysis of gene differential expression in sugarcane and other plants. AJCS 7:659-664

Weising K, Nybom H, Wolff K. Kahl G. 2005. DNA Fingerprinting in Plants. Principles, Methods, and Applications. 2nd ed. CRC Press, Boca Rayton, 472 pp.
Uotila P.1996. Decline of Anemone patens (Ranunculaceae) in Finland. Symb. Bot. Ups. 31:205-210.

Vergeer P, Rengelink R, Copal A, Ouborg NJ. 2003.The Interacting Effects of Genetic Variation, Habitat Quality and Population Size on Performance of Succisa pratensis. J Ecol. 91:18-26.

Willdenow, C.V. 1800. Species Plantarum, ed. 4. Impensis GC Nauk, Berolinum [Berlin].

Zohary M. 1963a. Taxonomical studies in Alcea of southwestern Asia. Part I. Bulletin of the Research Council of Israel 11:210-229.

Zohary M. 1963b. Taxonomical studies in Alcea of southwestern Asia. Part II. Israel Journal of Botany 12:1-26.

Zohary M. 1972. Malvaceae in Flora Palaestina. The Israel Academy of Science and Humanities, Jerusalem 2:311-329. 